\title{
Transboundary fisheries, climate change, and the ecosystem approach: taking stock of the international law and policy seascape
}

\author{
Cecilia Engler ${ }^{1}$
}

\begin{abstract}
The ecosystem approach to fisheries management is a conceptual and practical framework consistent with, and supportive of, climate change adaptation at the national and regional level. Implementing an ecosystem approach can contribute to climate change adaptation by improving ecosystem resilience and reducing vulnerability to climate change, by providing planning strategies and tools to monitor and assess the impacts of climate change on fisheries, and by relying on precautionary, flexible, and adaptive approaches that account for the uncertainties, surprises, unpredictability, and dynamism of ecosystems in a changing climate.
\end{abstract}

In this article, I provide an overview of some key considerations framing the mandate and capacity of regional fisheries management organizations and arrangements to implement ecosystem approaches in the context of climate change. The article first addresses the extent to which international law of the sea, and in particular the 1995 United Nations Fish Stock Agreement, endorses and implements an ecosystem approach to fisheries for the management of straddling and highly migratory stocks. It then addresses the barriers to more effective implementation of an integrated and adaptive ecosystem approach to fisheries in transboundary settings, including the decentralized and consensus-based nature of international law, stationary visions of ecosystems, and principles of certainty and stability. This analysis is then expanded to focus on specific challenges of adapting to climate-induced changes to transboundary stocks distribution and abundance. I address preparing and planning for climate change, responsive decision-making procedures, regulation of new fisheries, jurisdictional challenges, enhancing marine resilience, and revisiting allocation agreements, highlighting legal provisions and policy developments that may support or enhance the adaptive capacity of transboundary fisheries arrangements. I conclude that, despite some supportive legal provisions and practices, structural, legal, and political barriers severely hinder the pace and the scope of required governance and management responses to climate-induced changes to transboundary stocks.

Key Words: adaptive management; climate change; ecosystem approach to fisheries; integrated management; law of the sea; ocean acidity; regional fisheries management organizations or arrangements

\section{INTRODUCTION}

Over the past 30 years, the evidence and understanding of the impacts of anthropogenic greenhouse gas (GHG) emissions on the climate system, including oceans, have strengthened (IPCC 2019). The recent "Special Report on the Ocean and Cryosphere in a Changing Climate" (IPCC 2019) describes multiple, interconnected, intense, and accelerating processes of change in all ocean areas. Oceans have warmed and the rate of warming is likely increasing; marine heatwaves are more frequent, longerlasting, intense, and extensive; oceans have acidified; upper ocean has been stratifying and experiencing oxygen loss, with hypoxic areas ("dead zones") expanding in coastal areas; sea ice cover has decreased; global mean sea level is rising and accelerating; extreme wind, rainfall, and sea level rise associated with tropical cyclones have intensified, exacerbating extreme sea level rise and coastal hazards; and ocean circulation systems are changing (IPCC 2019). These climate-induced changes, together with nonclimatic pressures from human activities, are impacting marine primary production, marine organisms at multiple trophic levels, community composition, and ecosystem structure. Observations and projections point to poleward shifts in the distribution and biomass of pelagic species as well as distribution shifts to deeper waters; altered seasonal timing of species' activities; habitat compression; changes in species' abundance, migration patterns, reproduction, and growth; reduction in body size; increased mortality; and risk of local extinction (IPCC 2019).

The observed and projected changes threaten ecosystem services, including provisioning services such as fisheries. Global maximum catch potential is projected to decrease in the $21 \mathrm{st}$ century, but with regional variations both in the direction and rate of change. The distribution and composition of exploited species will likely be altered (IPCC 2019). The frequency and intensity of extreme climate events can cause increased mortality, changes in primary productivity, distribution shifts, and disruptions to fishing activities (IPCC 2019). Climate change will also increase uncertainty and affect the accuracy of management advice, because it will likely shift the baseline oceanographic conditions considered in stock assessment models (Cheung et al. 2019). Some of these impacts have already occurred and risks increase with increasing GHG emissions (IPCC 2019). Thus, addressing climate change is already an imperative for fisheries management at the local, national, and regional level.

The ecosystem approach to fisheries management (EAFM) is generally considered a conceptual and practical framework consistent with, and supportive of, climate change adaptation (OECD 2010, de Young et al. 2012, Porter et al. 2014, Heenan et al. 2015; see also Pinsky and Mantua 2014, Shaw et al. 2014, Barange et al. 2018, Rayfuse 2019). The EAFM is a sectoral implementation of ecosystem approaches (EA) to management (CBD 2000). As a distinctive feature, it is an integrated or holistic approach that places resource assessment and management in the context of the whole system, i.e., the dynamic complex of biotic and abiotic components interacting as a functional unit (CBD 2000, FAO 2003, Engler 2015). EAFM "strives to balance diverse societal objectives, by taking into account the knowledge and uncertainties about biotic, abiotic, and human components of 
ecosystems and their interactions and applying an integrated approach to fisheries within ecologically meaningful boundaries" (FAO 2003:14). The EAFM has been endorsed by international fora (FAO 2002, UN 2002, UN 2015, UNGA 2019) as the main framework for managing fisheries and implementing the principles of sustainable development.

The EAFM can contribute to climate change adaptation in several ways. First, by balancing conservation, sustainable use and fair allocation of natural resources (Heenan et al. 2015) the EAFM maximizes the resilience of stocks and ecosystems (Porter et al. 2014) and reduces the vulnerability of fisheries systems to climate change (de Young et al. 2012). Second, the integrative nature of EAFM provides the planning strategy and tools to monitor and assess the impacts of climate change on fisheries to inform management decisions through planned adaptations (de Young et al. 2012). Indeed, the risks of climate change and ocean acidification are part of the wider set of drivers affecting fisheries systems (Heenan et al. 2015) that are integrated into fisheries management under an EA. Third, the EAFM requires precautionary, flexible, and adaptive approaches to account for the uncertainties, surprises, unpredictability, and dynamism inherent to complex social-ecological systems (Karkkainen 2002, Engler 2015, Heenan et al. 2015, Long et al. 2015) and which will intensify as climate change progresses (de Young et al. 2012, Porter et al. 2014).

In this article I provide an overview of the international law and policy framing the mandate and capacity of regional fisheries management organizations and agreements (RFMO/As) to implement integrative and adaptive ecosystem approaches to transboundary fisheries management in the context of climate change. While taking stock of the international law and policy seascape, I explore features supportive of climate change adaptation, systemic barriers, and potential ways forward. These insights also provide a general background to the case studies included in this Special Feature (Koubrak and VanderZwaag 2020). I address first the extent to which the law of the sea, and in particular the 1995 United Nations Fish Stock Agreement (2167 UNTS 3, hereinafter UNFSA) endorses and implements an EAFM for straddling and highly migratory stocks. I address barriers to a more effective implementation of an integrated and adaptive EA in transboundary settings, drawing from the extensive scholarship addressing legal implications of ecosystem management, social-ecological resilience, and adaptive governance (see Humby 2014, Frohlich et al. 2018 for literature reviews), and outline the approaches adopted by RFMO/As to overcome those barriers. I further expand the analysis to the specific challenges of adapting to climate-induced changes to transboundary stocks' distribution and abundance..

\section{THE ECOSYSTEM APPROACH IN INTERNATIONAL FISHERIES LAW}

The 1982 United Nations Convention on the Law of the Sea (1833 UNTS 397, hereinafter UNCLOS) was not drafted with ecosystem considerations in mind (Molenaar 2002, Engler 2015), although some of its provisions have been interpreted as opening the doors for the implementation of an EA (Diz Pereira Pinto 2012; see also Wolfrum and Matz 2000, 2003). Rather, UNCLOS adopted a zonal and sectoral approach in defining the jurisdictional entitlements and management and conservation obligations of states. Coastal states exercise management rights and responsibilities (subject to some minimal and largely unenforceable obligations to fishing states regarding the allocation of surplus stocks) over the 200 nautical mile exclusive economic zone (EEZ), and, in the case of sedentary species, beyond the EEZ to any areas of extended continental shelf jurisdiction. In the high seas area beyond 200 nautical miles, fishing is a (qualified) freedom of the high seas (UNCLOS Article 87) and subject to flag state jurisdiction (UNCLOS Article 92).

In relation to marine living resources, the UNCLOS regime is predominantly exploitation oriented (Wolfrum and Matz 2000) and with a bias for single-species management. States are required to adopt conservation and management measures designed to maintain or restore populations of harvested species at levels that can produce the maximum sustainable yield (as qualified by relevant environmental and economic factors, UNCLOS Arts. 61, 119). For shared stocks (stock or stocks of associated species occurring within the EEZs of two or more coastal states), straddling stocks (stock or stocks of associated species occurring within the EEZ and in an area beyond and adjacent to the zone), highly migratory species (listed in Annex I of UNCLOS), and living resources in the high seas, UNCLOS simply encourages or requires cooperation between coastal states and states fishing for the same resources in the high seas, either directly or through regional or subregional organizations (UNCLOS Arts. 63, 64, 118).

The conflicting interests of coastal and fishing states, coupled with the imprecise cooperation obligations set out in UNCLOS, led to a period of significant disputes over, and overutilization of, both straddling stocks (e.g., the northwest Atlantic fisheries off the coast of Canada) and highly migratory stocks (most prominently in the western and central Pacific). In 1992, the United Nations Conference on Environment and Development adopted Agenda 21, which called for states to convene an intergovernmental conference under United Nations (UN) auspices with a view to promoting effective implementation of the provisions of UNCLOS (UNCED 1992). The intergovernmental conference adopted UNFSA in 1995. The Agreement strengthens Articles 63 and 64 of UNCLOS by institutionalizing the obligation to cooperate in the conservation and management of straddling and highly migratory stocks in RFMO/As and strengthening the obligation for states to comply with and enforce the rules put in place by RFMO/As. Importantly for the purposes of this article, UNFSA also introduced modern principles of sustainable development (UNFSA: Preamble 96-7, Orrego Vicuña 1999) reflected inter alia in the 1992 United Nations Conference on Environment and Development, the 1992 International Conference on Responsible Fisheries, and the Food and Agriculture Organization of the United Nations (FAO) 1995 Code of Conduct for Responsible Fisheries. For example, the Agreement's objective is to ensure the long-term conservation and sustainable use of straddling and highly migratory stocks (UNFSA Article 2), and the precautionary approach is mandated for the conservation, management, and exploitation of stocks (UNFSA Article 5 and Annex II).

The EAFM is not explicitly mentioned in the Agreement. Nevertheless, several of its provisions reflect a more holistic and adaptive approach to fisheries management, making it "more 
clearly based upon" the EA (Wolfrum and Matz 2003:22). The Agreement recognizes the need to manage fish stocks in their entirety, taking into account their biological unit (Article 7). It also calls for assessing the impact of fishing, other human activities and environmental factors not only on target stocks but also on species belonging to the same ecosystem or associated with or dependent upon the target stocks (UNFSA Article 5(d), [emphasis added]). Where appropriate, the RFMO/As should also adopt conservation and management measures for nontarget species (albeit only to maintain or restore populations of such species above levels at which their reproduction may become seriously threatened, UNFSA Article 5(e)). The Agreement further calls to minimize pollution, waste, discard, catch by lost or abandoned gear, by-catch (Article 5(f)), and more broadly to protect biodiversity in the marine environment (Article 5(g)).

From a procedural perspective, the Agreement requires RFMO/ As to ensure that conservation measures are based on the best scientific evidence available (Article 5(b)), and to implement improved techniques for dealing with risk and uncertainty in the context of the precautionary approach (Article 6.3(a)). It also requires taking into account existing and predicted oceanic, environmental, and socioeconomic conditions (Article 6.3(c)), a provision that supports the integration of climate models in the assessment of conservation and management measures. Sharing research on environmental factors affecting stock abundance and oceanographic and ecological studies is required where appropriate (UNFSA Annex 1 Article 3.2(c)).

\section{BARRIERS TO AN ECOSYSTEM APPROACH TO TRANSBOUNDARY FISHERIES MANAGEMENT}

The UNFSA provisions described above significantly advanced the conventional international standards for fisheries management of straddling and highly migratory stocks (Orrego Vicuña 1999). Nevertheless, these modern international standards are to be implemented in the context of established legal frameworks, principles, and practices, which are not necessarily consistent with the holistic and adaptive nature of EAFM.

One area of tension is the "structural barriers" (Rayfuse 2015) or "root challenges" (UNEP 2016) affecting RFMO/As performance generally. These include the general principle that a treaty does not create either obligations or rights for a third state without its consent (pacta tertiis nec nocent nec prosunt, Article 34 of the Vienna Convention on the Law of Treaties, 1155 UNTS 331), a principle underlying both the "free rider" problem and the consensus-based decision-making process traditionally favored in RFMO/As. The (qualified) freedom of the high seas and the primacy of flag state responsibility further contribute to difficulties in exhorting and enforcing cooperation for transboundary fisheries management. Further challenges result from the inherent tension between the integrative and adaptive approaches called for in an EA and fundamental features of legal systems (Owen 2013, Cosens et al. 2017): the fragmented nature of environmental and international law; and certainty and stability as core values of legal systems.

Environmental law and the law of natural resources traditionally regulated environmental problems media by media, sector by sector, and issue by issue, resulting in a fragmented landscape of regulatory regimes and responsible institutions. That is true both in a national and international context (Scott 2011, Owen 2013), including international environmental law and the law of the sea (UN Secretary-General 2018; Molenaar and Caddell 2019). UNFSA builds on and perpetuates the zonal and sectoral approaches of UNCLOS. From a zonal perspective, it institutionalizes the obligation to cooperate in "regional" fisheries management organizations or arrangements (UNFSA, Article 8), with the geographical area of competence identified considering the area of distribution of the target stock(s) (UNFSA Article 9.1(b) with reference to Article 7.1) together with environmental, social, and political factors (UNFSA Article 9.1(b), UNEP 2016). This results in the allocation of fisheries management responsibilities across a patchwork of organizations, generally with fixed geographical boundaries. Additionally, many RFMO/ As have competence to adopt conservation and management measures only for the high seas portion of the stock (UNFSA, arts. 3, 4, 7; UNEP 2016). From a sectoral perspective, RFMO/ As' mandates are focused on target fish stock development and management. The membership of the organizations is limited to states with "real interest" in the stocks (UNFSA, Article 8), a term that has been generally interpreted by states as a fishing interest (but see Molenaar 2000, 2019). The fisheries focus has, in turn, dictated the structure of the organizations (e.g., the International Commission for the Conservation of Tunas' panels), the professionals appointed by states to its meetings (Tudela and Short 2005, FAO/GEF 2016, Koubrak and VanderZwaag 2020), and the data collected (e.g., UNFSA, Annex I).

Although UNFSA considers a broader obligation to protect biodiversity in the marine environment, this obligation needs to be interpreted in the context of the UNFSA objective, that is, ensuring the long-term conservation and sustainable use of straddling and highly migratory stocks (Tladi 2015). Biodiversity objectives will need to be balanced with short-term and stockspecific fisheries objectives; in a context of consensus-based decision making, RFMO/As almost invariably prioritize the latter. Ongoing debates in the Commission for the Conservation of Antarctic Marine Living Resources (CCAMLR) related to the interpretation of its objective and in particular the relationship between conservation and rational use is a case in point (Brooks 2013, Smith et al. 2016).

Certainty and stability, in turn, are important values in legal systems and are reflected in cornerstone institutions such as codification (in civil law) and stare decisis (in common law), or institutions such as grandfathering rights (see Craig 2010, Green et al. 2015, de Caro et al. 2017). Furthermore, early environmental law considered the environment itself as a stable entity and strived to "restore" anthropogenically intervened systems to their natural stable state (Craig 2010). Both aspects of stability are reflected in international fisheries law and in long-standing fisheries management practices, contributing to the rigidity and possible maladaptation of transboundary management regimes. The objective of maintaining or restoring populations of harvested species "at levels which can produce the maximum sustainable yield" (UNCLOS, arts. 61, 119) assumes stocks are in a state of natural equilibrium and susceptible of quantification. The notion that fisheries management is best addressed at the regional level through an institutional entity enshrined in an international agreement (generally with fixed boundaries) assumes a relatively stable and immutable distribution of the stocks. It also assumes 
that the participants in the fisheries and in the agreement are a stable and immutable group of states with "real interest" (UNFSA, Article 8.3), a "lock-in" that explains the excruciating difficulties in accommodating new entrants documented elsewhere (Molenaar 2003). The decision-making procedures of RFMO/As, often relying on consensus or unanimity as a consequence of the consensus nature of international law, are also supportive of the status quo (Harrison 2019).

Perhaps the most rigid element of transboundary fish management regimes are the allocation agreements. Allocation of quota (or effort) is a key conservation and management measure in most RFMO/As (UNFSA, Article 10(b)), and one of the most difficult aspects of cooperative management. Allocation has relied on mainly two criteria that assume stability and seek to perpetuate the status quo. Zonal attachment, reflected in Article 7.2(d) of UNFSA, assumes a stable distribution of stocks inside areas of national jurisdiction and in the high seas. Historical catches, a criterion reflected generally in the concept of existing fisheries or existing fishing patterns and practices in Articles 7.2 (d) and 11(b) of UNFSA, recognizes and protects the fishing status quo, often at unsustainable levels (Engler 2010). Furthermore, the sharing agreement itself strives for stability. RFMO/As usually roll over past agreements with minimal changes (Engler 2010). The expectation of stability is sometimes stated explicitly, such as through the principle of "relative stability" guiding the Common Fisheries Policy (EU 2013), the limit to total allowable catch (TAC) interannual variation in the harvest control rule adopted for the Northeast Arctic cod (Gadus morhua) by the Joint Norwegian-Russian Fishery Commission (Kvamsdal et al. 2016), or multiannual sharing agreements.

RFMO/As have endeavored to overcome the tensions between key features of EAFM and legal principles and long-standing management practices, as well as the "structural barriers" of RFMO/As, in several ways. They include the efforts to fill governance gaps in international fisheries management by establishing new RFMO/As. Additionally, several initiatives have sought to "strengthen" RFMO/As (UNFSA, Article 13). For example, several organizations have modified constituent instruments to explicitly include modern management standards, including EAFM, consistent with the provisions of UNFSA, or have committed to those standards through policy decisions. Most RFMO/As have established ecosystem working groups or include ecosystem considerations in the agendas of both scientific and decision-making bodies. Some RFMOs' conventions allow the adoption of decisions by majority vote when consensus cannot be reached and limit the use of objection procedures. Regular performance reviews have improved accountability and transparency. Institutional cooperation (UNFSA, Article 8.6, Scott 2011, Harrison 2019) has also been pursued with cooperation among RFMO/As and between RFMO/As and other multilateral environmental agreements (UNEP 2016) increasingly in their agendas. Additionally, global fora, in particular the UN General Assembly (UNGA) and the UNFSA Review Conference, have been influential in improving interinstitutional coordination, identifying best practices, highlighting common challenges, and setting higher standards for RFMO/As'substantive and procedural performance (see Caddell 2019).
Despite these initiatives, implementation of the EAFM has been slow and uneven (Juan-Jordá et al. 2018, Haas et al. 2020, Koubrak and VanderZwaag 2020). In most cases, RFMO/As' work on ecosystems has focused on minimizing impact to by-catch species, with very limited integration of broader ecosystem considerations such as ecosystem properties, trophic relationships, habitat protection, cumulative impacts, or multiple drivers (Juan-Jordá et al. 2018, Haas et al. 2020; see also Link and Browman 2014; for a broader road map for EAFM in NAFO see Koen-Alonso et al. 2019).

The implementation of area-based tools provides a clear example of the tensions between modern fisheries standards and traditional legal frameworks and principles. Concerns about the conservation of marine biodiversity in areas beyond national jurisdiction led the international community to call upon RFMO/ As to prevent significant adverse impacts on vulnerable marine ecosystems (VME) from bottom fishing (UNGA 2006) and, more broadly, to develop and implement area-based tools, including marine protected areas, for the management of fisheries and for the protection of marine ecosystems (e.g., UN 2002, UNFSA Review Conference 2006, 2010, 2016). RFMO/As have responded to these expectations to various degrees. Several nontuna RFMOs have taken measures to protect VME, including closing areas for all, or for specific, bottom fishing gears (Bell et al. 2019, Ortuño Crespo et al. 2020). Particularly commended have been the efforts of the North East Atlantic Fisheries Commission to cooperate with the OSPAR Commission, a regional seas program with an environmental mandate, to coordinate their respective area-based tools and ensure multisectoral policy coherence (Kvalvik 2012, Freestone et al. 2014, Smith and Jabour 2018; see also UNEP 2016). Pelagic closed areas are less frequent (Ortuño Crespo et al. 2020). CCAMLR stands out as establishing both the first and the largest MPA in the high seas (South Orkney Islands Southern Shelf and Ross Sea, respectively; see Smith and Jabour 2018). It is noteworthy that the objectives for the establishment of these MPAs consider not only conserving key natural ecological structures, dynamics, and functions (CCAMLR 2009a, 2016a) but also providing scientific reference areas (CCAMLR 2009a), including for monitoring natural variability and long-term change and to gauge the ecosystems effects of climate change (CCAMLR 2016a).

Although these efforts clearly demonstrate progress in implementing EAFM, they have faced several challenges. Areabased measures in areas beyond national jurisdiction are "few, static and sectoral" (Ortuño Crespo et al. 2020). All processes have required considerable "time and effort" (Freestone et al. 2014; see also Kvalik 2012), and the need for consensus has repeatedly blocked the adoption of measures (Brooks 2013). Area-based conservation tools are often designed to limit their interference with fishing interests, sometimes against scientific advice (Brooks 2013, Smith and Jabour 2018). The RFMO's legal capacity to adopt no-take area-based measures was repeatedly questioned by state parties (Brooks 2013, Smith and Jabour 2018). Multisectoral cooperation, in turn, has largely not been achieved (Freestone et al. 2014).

The negotiation of an international legally binding instrument on the conservation and protection of marine biodiversity in areas beyond national jurisdiction (ILBI-BBNJ; UNGA 2018) 
responds to the procedural and substantive limitations of the fragmented legal landscape. Nevertheless, there is considerable uncertainty on whether, and how, the proposed new regime will interact with regional fisheries management and UNFSA. The negotiating parties have stressed that the agreement shall be "interpreted and applied in a manner that [respects the competences of and] does not undermine relevant legal instruments and frameworks and relevant global, regional, subregional and sectoral bodies" (UNGA 2020). Arguably, the sectoral fragmentation of international law serves political and economic interests.

\section{FOCUSING ON CLIMATE CHANGE: CHALLENGES FOR TRANSBOUNDARY FISHERIES MANAGEMENT}

The previous sections provided an overview of the international legal and policy seascape addressing EA for transboundary fisheries management. They highlight the tensions between the holistic, precautionary, adaptive, and flexible approaches required under EAFM and long-standing international legal rules, principles, and practices that favor fragmentation, promote stability, and protect the status quo. These tensions will intensify in the context of increasing climate variability and change. Changes in fish stocks' distribution and abundance and in ecosystem composition, together with increased variability and uncertainty, will challenge RFMO/As' jurisdictional and institutional settings, scientific and decision-making processes, and management objectives and approaches. I address some of these challenges, expanding the analysis of the previous section and providing an overview of legal provisions and policy developments that may support and enhance RFMO/As' adaptive capacity.

\section{Preparing and planning for climate change}

To date, RFMO/As have generally addressed climate-induced changes in their scientific or ecosystem subsidiary bodies in an ad hoc manner. Only some include climate-related research in their scientific work plans or strategies (e.g., CCSBT 2015) although with relatively low priority (CCSBT 2017, Rayfuse 2019). The institutional capacity to address climate and oceanographic changes is reportedly lacking (FAO/GEF 2016, NAFO 2018, Koubrak and VanderZwaag 2020). Institutional cooperation with climate data and research institutions has generally not been pursued despite explicit recommendations (UNFSA Review Conference 2016, FAO 2016, CCAMLR 2018, NAFO 2018).

Climate change is sometimes implicit in stock assessments or management strategy evaluations as an environmental driver of variability (e.g., CCSBT 2018, Koen-Alonso et al. 2019). This approach avoids the potentially contentious issue of attribution and responds to space and time scales that are relevant for fisheries management (Reid 2018, IPCC 2019). However, it begs the question of whether it is sufficient to understand and prepare for the different paths in which climate change may affect the work of RFMO/As beyond stock assessment and TAC setting (Carlarne and Eagle 2012, Pentz and Klenk 2020).

Strategic and comprehensive planning has been lagging (Pentz and Klenk 2020). Even the organization with the strongest record in EA implementation, CCAMLR, has had difficulties advancing strategic consideration of climate change. In 2009, CCAMLR adopted a resolution limited to "urging" increased consideration of climate change impacts in the Southern Ocean to better inform CCAMLR management decisions, and to "encouraging" all CCAMLR Parties to actively contribute toward relevant science initiatives (CCAMLR 2009b). A more concrete proposal to adopt a "Climate Change Response Work Program" addressing both science and management implications of climate change to Southern Ocean fisheries has not reached consensus in the Commission (CCAMLR 2018). Another proposal to introduce scientifically based climate change implications statements to the Commission and Scientific Committee working papers was also defeated but will be implemented on a voluntary basis by some members (CCAMLR 2018). More recently, the Western and Central Pacific Fisheries Commission (WCPFC) adopted, after extensive discussion, a nonbinding resolution on climate change as it relates to the WCPFC. The resolution seeks to consider the potential impacts of climate change on the economies of its members and cooperating members as well as food security and livelihoods of their people. It further encourages scientific research on the relationships between climate change and target and nontarget species, including interrelationship with other factors that affect them, and the consideration of that scientific research in the Commission's deliberations and the adoption of conservation and management measures. Noteworthy, the resolution also includes an explicit but aspirational mitigation commitment, although limited to reducing the carbon footprint resulting from the work of the Commission and its subsidiary bodies rather than the fishing operations (see WCPFC 2019).

Long-term adaptation strategies to climate-induced changes to transboundary fisheries have not been adopted, although UNGA has encouraged RFMO/As to enhance cooperation for the development and implementation of adaptation strategies through exchange of data, research, and best practices (UNGA 2019). RFMO/As and their members could benefit from a sciencebased regional strategy for adaptation to climate change that guides the work of the organization as well as the national adaptation efforts of its members. A difficult aspect would be the extent to which RFMO/As would be willing and able to address climate vulnerability to livelihoods and food security. RFMO/As do not systematically address socioeconomic considerations of the fishery (Engler 2010, Koen-Alonso et al. 2019; but see WCPFC 2019) despite some provisions of UNFSA (see below).

\section{Responsive decision-making processes}

Climate change is expected to affect fisheries stocks and ecosystems in different ways, including progressive long-term changes, increased seasonal and decadal variability, increased occurrence of anomalies, and regime shifts as tipping points are reached. RFMO/As will need strategies to respond to these different impacts in a timely manner.

The institutionalization of cooperation and the complex structure of RFMOs (Harrison 2019) already facilitates an adaptive decision-making process based on the results of regular scientific assessments. Assuming that climate drivers of oceanic change are integrated in the assessment process, gradual changes can be accommodated within existing management practices (Diekert and Nieminen 2017). Abrupt changes (either as anomalies or regime shifts) will require different responses. UNFSA considers the need to adopt measures on an emergency basis in Article 6.7. 
If a "natural phenomenon has a significant adverse impact on the status of ... stocks, States shall adopt conservation and management measures on an emergency basis to ensure that fishing activity does not exacerbate such adverse impact." Emergency measures can apply also if the fishing activity itself presents a serious threat to the sustainability of the stocks. Although UNFSA uses the expression "natural phenomenon," a nonrestrictive interpretation of the term could include oceanographic and ecosystem changes caused by uncertain, cumulative, or indirect anthropogenic drivers.

Some RFMOs have agreed on protocols to address "exceptional circumstances," generally understood to occur when the stock moves outside the range of parameters compatible with the various scenarios considered in the MSE simulation testing (Arrizabalaga et al. 2018, NAFO 2019). If an exceptional circumstance is declared (and its severity evaluated), the Commission is to adopt precautionary measures, ranging from increased monitoring to reductions in TAC. Expediency can also be achieved through preagreed management responses to foreseeable events. For example, some organizations have agreed on sloping control rules, an adaptive harvest strategy that reduces exploitation rates with smaller stock size (Sigler et al. 2016). These measures may not have been adopted to address climate change, but they are examples of dynamic management in light of uncertainty and change.

Increased uncertainty will probably trigger technical or scientific disputes, as science progresses in understanding complex and interlinked phenomena that have significant consequences for management and for the different fishing interests at stake (Pinsky et al. 2018). Scientific disputes can paralyze decision making and contribute to the "response gap" of RFMO/As (Pentz and Klenk 2017). UNFSA provides a mechanism to address technical disputes expeditiously by referring it to ad hoc expert panels (UNFSA, Article 29), a mechanism that has been used successfully in the past (e.g., CCSBT 1999). RFMOs could consider establishing rules and procedures for the establishment of such expert panels on a pre-emptive basis.

\section{New fishing opportunities}

Climate-induced distribution and ecosystem shifts will likely result in the opening of new fisheries with commercial potential, which in turn represents significant challenges for ensuring timely, precautionary, and sustainable management. The structural barriers of RMFO/As discussed above have, in practice, provided pervasive incentives for unsustainable fishing that has led to stock collapse before management measures can be agreed on (Engler 2010).

New or exploratory fisheries have been addressed in Article 6.6 of UNFSA in the context of the precautionary approach to fisheries management. The provision requires states to adopt cautious conservation and management measures as soon as possible, gather data, assess the impact of the fishery on the longterm sustainability of the stock, and implement measures based on that assessment, including the gradual development of the fishery if appropriate. More specific standards have been developed by some RFMO/As (e.g., CCAMLR and South Pacific RFMO), and by the UNGA resolutions on the protection of vulnerable marine ecosystems (UNGA 2006, 2009) and FAO Guidelines on Deep Sea Fisheries (FAO 2009; see also Caddell
2018). Stronger measures have also been agreed for formerly sea ice covered areas that have the potential to support commercial fisheries in the future. The parties to the Agreement to Prevent Unregulated High Seas Fisheries in the Central Arctic Ocean, signed in 2018, committed to authorize commercial fisheries in that area of the high seas only after precautionary conservation and management measures are established (Article 2, 3.1 and 5.1). It also requires the establishment of a Joint Program of Scientific Research and Monitoring (Article 4), which has not been finalized yet. CCAMLR, in turn, designated time-limited special areas for scientific study in newly exposed marine areas following ice-shelf retreat or collapse (CCAMLR 2016b, Rayfuse 2018).

In other cases, the implementation of the UNFSA provisions for new or exploratory fisheries may be difficult considering the underlying principle of (qualified) freedom to fish in the high seas, decision-making processes of RFMO/As, and the economic incentives leading to "boom and bust" cycles. Noncompliance by free riders, in turn, remains a challenge despite efforts to address it through market and port measures (see generally Stokke 2019). Further substantive or procedural strengthening of the international regime for new fisheries could result from the ILBIBBNJ under negotiation. This agreement could, for example, require an environmental assessment at least for new fisheries that do not fall under the jurisdictional mandate of an existing RFMO/ A (Wright et al. 2016, UNGA 2020), outline minimum standards (UNGA 2020), or strengthen accountability and transparency (UNGA 2020).

\section{Jurisdictional challenges}

Distribution shifts or expansion of regulated fisheries could potentially extend beyond the generally fixed boundaries of an RFMO/A, leaving part of the stock outside its regulatory purview. If the stocks' distribution extends to an adjacent area of the high seas where no RFMO/A with competence over the species exist, members may need to amend the boundaries of the RFMO or make arrangements to extend the adopted conservation and management measures to the adjacent area. Practical arrangements may prove more flexible than an amendment of the organizations' boundaries, in particular if there is uncertainty about the permanency of the shift or it affects only one, or a subset, of species managed by the RFMO.

The situation is different if the stock shifts to an area where an existing RFMO/A has competence for that species, into areas under sovereign rights of coastal states, or if nonmembers commence fishing activities in the adjacent area before an arrangement is put in place. In all these cases, the substantive management of the shifting species will require new rounds of negotiations to coordinate with other organizations or to accommodate new fishing rights and interests. Early examples of this are the informal agreement between the Northwest Atlantic Fisheries Organization (NAFO) and the North-East Atlantic Fisheries Commission (NEAFC) to address the distribution shift of the pelagic oceanic redfish and the challenges that the northern shift of Atlantic bluefin tuna (Thunnus thynnus) represent for the International Commission for the Conservation of Atlantic Tunas (ICCAT; Koubrak and VanderZwaag 2020).

\section{Enhancing marine resilience}

The broader integration of ecosystem and climate considerations into fisheries management would require the definition, 
assessment, and balancing of multiple ecosystem objectives (Link and Browman 2014, FAO/GEF 2016). Those ecosystem objectives may be in conflict with each other and, in particular, with short-term fisheries objectives. An EAFM is likely to require lowering exploitation rates and total allowable catch (Tudela and Short 2005). Managing for ecosystem resilience to climate change will require reducing other anthropogenic stressors, including fisheries (McIlgorm et al. 2010, Craig 2017, Diekert and Nieminen 2017), and the protection of significant ocean areas through marine protected areas or marine reserves as an adaptation measure (Grafton 2010, Barange et al. 2018).

The fragmented and nonhierarchical (decentralized) international fisheries governance system is ill-equipped for assessing and balancing trade-offs (Wolfrum and Matz 2003, Friedman et al. 2018). Although the Intergovernmental Panel on Climate Change (IPCC) highlighted the need for the international community to progress rapidly to a "whole of ocean" strategy for responding to the risks and challenges posed by anthropogenic ocean warming and acidification (Hoegh-Guldberg et al. 2014:1661), there are only a few, and rather ineffective, avenues that can facilitate that collaborative problem-solving. Whether the ILBI-BBNJ can contribute to the international legal seascape by fleshing out substantive or procedural mechanisms to balance conflicting objectives in the law of the sea remains to be seen. Other proposals, such as establishing a centralized high seas fisheries system (Telesetski 2014) or a complete closure of high seas fisheries to improve resilience of the ocean (Brooks et al. 2014, Craig 2017) represent a departure from the principle of (qualified) freedom of fishing on the high seas that would demand decisive and as yet unshown global political will.

Soft law initiatives may lead to political pressure to seek high-level policy coordination between fisheries, diversity, and resilience objectives, perhaps giving specific content to the obligation to protect biodiversity in the marine environment under UNFSA (Article 5(g)). A resolution by the Conference of the Parties to the United Nations Framework Convention on Climate Change addressing oceans (Scott 2017) could call for RFMOs to address resilience of the marine environment and marine resources considering the cumulative pressures of fisheries and climate change and to propose a specific and time-bound action plan to that end. Although early on the oceans were ignored by the climate change regime (Freestone 2009), current developments are providing a stronger basis for integrated and cooperative action (Because the Ocean Declaration 2015, IPCC 2019). UNGA, the UNFSA Review Conference, and UN Oceans could also strengthen efforts to coordinate the work of different sectoral organizations in addressing multiple ecosystem objectives. Influential states, coalition of states, or RFMO/As could also show leadership in this regard.

\section{Revisiting allocation agreements}

Shifts in the distribution and abundance of stocks will produce, as is often stated, "winners and losers" among nations (HoeghGuldberg et al. 2014:1660, Sumaila et al. 2020). Climate change has already had and will continue to have distributional consequences for fisheries management. The distribution of natural resources has been a main driver of the development of international law of the sea, and at the core of RFMOs' mandates. It is still to a significant extent an unsettled issue, and conflicts are likely to become more frequent with climate change, either as a result of shifts in distribution or abundance.

Distribution shifts from the EEZ to the high seas or vice versa may trigger situations of "double jeopardy" or unsustainable competing harvesting (Pinsky et al. 2018, Rayfuse 2019). Shifting stocks can also affect the balance of interests reflected in sharing agreements, if compatibility of measures adopted for the EEZ(s) and the high seas are based on the assessment of the zonal attachment of the stocks. A reassessment of that criterion based on new factual circumstances may be needed. Preagreed criteria, indicators, process, and time line for reassessment may abate scientific and policy conflict and uphold cooperative action (see, e.g., NEAFC 2017, Palacios-Abrantes et al. 2020).

Sharing agreements can also be destabilized by new participants, for example, if the stock shifts to the EEZ of a nonmember coastal state or to the area of the high seas under the jurisdiction of another RFMO/A. Accommodating new participants in the fishery would entail restricting existing fisheries opportunities and affecting the status quo, a decision that is usually resisted even at the expense of sustainability.

Challenges to sharing agreements can also result from reductions of exploitable biomass. Gradual changes in abundance are more likely to be accommodated within existing assessment and management processes (Diekert and Nieminen 2017), although reductions in TACs are usually resisted. Agreements to share metric tonnes rather than a percentage of TAC are inherently less resilient.

Loss of fishing opportunities may also result from lack of adaptive capacity. For example, there may be a need to adapt the fishing fleet and gear to fish at greater distances or water depths. Lack of adaptive capacity may also limit the ability of some members to participate in new fisheries. If historical catches are used as a predominant criterion for allocation of fishing opportunities once the fishery is established as a commercial fishery, the lack of adaptive capacity to take advantage of new opportunities will translate in reduced fishing opportunities in the long term.

Transferable quotas, other tradable right-based systems, and side payments are often suggested as a means to improve flexibility of fisheries management arrangements (OECD 2010, Aqorau et al. 2018, Palacios-Abrantes et al. 2020). These systems allow reallocation of fishing opportunities to adapt to situations of operational or economic inefficiency resulting from distribution or abundance shifts. The practice of quota trading among members is common in most RFMOs. However, these economic measures do not necessarily address socioeconomic impacts, in particular food security and employment (Ojea et al. 2017).

Establishing high level principles for oceans and adaptation, with references to climate justice issues of access to fisheries, has been suggested to integrate oceans and climate (Scott 2017). To date, climate justice arguments have not been put forward in the RFMOs' work on allocation (e.g. ICCAT 2016, IOTC 2019), and they would likely be resisted. Even in the absence of such highlevel policy, RFMOs could address some of the distributional concerns resulting from shifting stocks through increased visibility and practical application of some of the UNFSA provisions relevant to allocation. These include Articles 24 and 
25 addressing recognition of the special requirements of developing states and forms of cooperation with developing states, respectively. Particularly relevant are the provisions that call for states, directly or through regional or global organizations, to enhance the ability of developing states to develop their own fishery for transboundary stocks and to participate in high seas fisheries. Articles 5(i), 7.2(e) and 11(d)-(e) in turn recognize dependency on fisheries as a criterion to consider in the adoption of management measures, particularly in allocation of fishing opportunities. An RFMO's adaptation strategy could advance those concepts and pre-empt disputes that are costly both for the organization and for the sustainability of marine resources.

\section{CONCLUDING REMARKS}

Integrative and adaptive EA are widely considered an imperative for transboundary fisheries management and will become more relevant in the context of climate-induced changes to the marine ecosystem. Indeed, climate change highlights and reinforces the need to manage fish stocks with full consideration of the complexity, uncertainty, and unpredictability of dynamic and deeply interconnected social-ecological systems.

UNFSA includes a number of provisions that frame RFMO/A responses to the complexity and dynamism of ecosystems and support adaptive capacity. Nevertheless, these provisions exist within a structure and objectives that follow legal principles and tenets in tension with integration and adaptation: the fragmentation of environmental law, international law, and the law of the sea; objectives aligned with stationary visions of ecosystems (Craig 2010); and the upholding of certainty and stability in the relationship and agreements between participating states. Reconciling these principles in tension has been a central challenge in the theory and practice of EA to management, particularly in the context of climate change (Karkkainen 2002, Craig 2010, 2013, Doremus 2010, Ruhl 2010, Green et al. 2015). In the case of RFMO/As, potential responses are further constrained by the decentralized and consensus-based nature of international law.

RFMO/As have already adopted some flexible arrangements, adaptive responses, and adaptive capacity, in some cases triggered by the need to respond to climate-induced changes to stocks distribution. Largely, however, these have been ad hoc responses. RFMO/A are yet to address climate change in a proactive and comprehensive manner. Strengthening the knowledge base and expertise, systematically addressing climate change in decisionmaking structures and processes (Rayfuse 2019), and building adaptive capacity and flexible cooperative mechanisms (including allocation agreements) will likely become a more prominent and explicit part of the work of RFMO/As.

The question that remains is whether the incremental implementation of EA to transboundary fisheries management will be sufficient to address increasing challenges (Pentz and Klenk 2020). The rate and scope at which RFMO/As have been introducing ecosystem considerations, including climate change, into management decisions (Koubrak and VanderZwaag 2020) may be outpaced by the rate and scale of ecosystem change (Pentz and Klenk 2020). Further, explicitly considering climate change in the implementation of the EA to transboundary fisheries management only addresses one side of the deeply interconnected ocean-climate relationship. The reconciliation of fisheries objectives with a broader goal of ensuring marine resilience to climate change is an aspect mostly unaddressed by RFMO/As, difficult to address within the sectoral fragmentation of the law of the sea, and would require strong global political will. Additionally, unresolved equity issues in the distribution of fishing opportunities for straddling and highly migratory stocks and the benefits and burdens of conservation measures will be reopened and exacerbated under climate change.

Responses to this article can be read online at: https://www.ecologyandsociety.org/issues/responses. $\mathrm{php} / 11988$

\section{Acknowledgments:}

This is a product of the OceanCanada Partnership funded by the Social Sciences and Humanities Research Council of Canada.

\section{Data Availability:}

Datalcode sharing is not applicable to this article because no new datalcode were created or analyzed in this study.

\section{LITERATURE CITED}

Aqorau, T., J. Bell, and J. N. Kittinger. 2018. Good governance for migratory species. Science 361(6408):1208-1209. https://doi. org/10.1126/science.aav2051

Arrizabalaga, H., G. Merino, H. Murua, and J. Santiago. 2018. Characterizing exceptional circumstances in ICCAT: a summary of experience in other RFMOs. ICCAT Collected Volumes of Scientific Papers 75(2):166-170. SCRS/2018/063

Barange, M., T. Bahri, M. C. M. Beveridge, K. L. Cochrane, S. Funge-Smith and F. Poulain, editors. 2018. Impacts of climate change on fisheries and aquaculture: synthesis of current knowledge, adaptation and mitigation options. FAO Fisheries and Aquaculture Technical Paper No. 627. Food and Agriculture Organization, Rome, Italy.

Because the Ocean Declaration. 2015. [online] URL: https:// oceans.taraexpeditions.org/wp-content/uploads/2015/12/Becausethe-Ocean-double-sided.pdf

Bell, J. B., E. Guijarro-Garcia, and A. Kenny. 2019. Demersal fishing in areas beyond national jurisdiction: a comparative analysis of regional fisheries management organisations. Frontiers in Marine Science 6:596. https://doi.org/10.3389/ fmars.2019.00596

Brooks, C. M. 2013. Competing values on the Antarctic high seas: CCAMLR and the challenge of marine-protected areas. Polar Journal 3(2):277-300. https://doi.org/10.1080/2154896X.2013.854597

Brooks, C. M., J. B. Weller, K. Gjerde, U. R. Sumaila, J. Ardron, N. C. Ban, D. Freestone, K. Seto, S. Unger, D. P. Costa et al. 2014. Challenging the 'right to fish' in a fast-changing ocean. Stanford Environmental Law Journal 33(3):289-324.

Caddell, R. 2018. Precautionary management and the development of future fishing opportunities: the international regulation of new and exploratory fisheries. International Journal 
of Marine and Coastal Law 33:199-260. https://doi. org/10.1163/15718085-13310013

Caddell, R. 2019. International fisheries law and interactions with global regimes and processes. Pages 133-164 in R. Caddell and E. J. Molenaar, editors. Strengthening international fisheries law in an era of changing oceans. Hart, Oxford, UK. https://doi. org/10.5040/9781509923373.ch-007

Carlarne, C., and J. Eagle. 2012. Food security, fisheries, and ecosystems. Pages 791-814 in M. B. Gerrard and K. Fischer-Kuh, editors. The law of adaptation to climate change: U.S. and international aspects. American Bar Association, Chicago, Illinois, USA.

Cheung, W. W. L., V. W. Y. Lam, Y. Ota and W. Swartz. 2019. Modelling future oceans: the present and emerging future of fish stocks and fisheries. Pages 13-24 in R. Caddell and E. J. Molenaar, editors. Strengthening international fisheries law in an era of changing oceans. Hart, Oxford, UK. https://doi.org/10.5040/9781509923373.ch-002

Commission for the Conservation of Antarctic Marine Living Resources (CCAMLR). 2009a. Conservation Measure 91-03 (2009) on Protection of the South Orkney Islands southern shelf. CCAMLR, Hobart, Australia.

Commission for the Conservation of Antarctic Marine Living Resources (CCAMLR). 2009b. Resolution 30/XXVIII on climate change, adopted by the Twenty-eighth Meeting of the Commission, Hobart, Australia, 26 October-6 November. CCAMLR, Hobart, Australia.

Commission for the Conservation of Antarctic Marine Living Resources (CCAMLR). 2016a. Conservation Measure 91-05 (2016) Ross Sea region marine protected area. CCAMLR, Hobart, Australia.

Commission for the Conservation of Antarctic Marine Living Resources (CCAMLR). 2016b. Conservation Measure 24-04 Establishing time-limited special areas for scientific study in newly exposed marine areas following ice-shelf retreat or collapse in Statistical subareas 48.1, 48.5 and 88.3, adopted by the Thirty-fifth Meeting of the Commission, Hobart, Australia, 17-28 October 2016. CCAMLR, Hobart, Australia.

Commission for the Conservation of Antarctic Marine Living Resources (CCAMLR). 2018. Report of the Thirty-Seventh Meeting of the Commission held in Hobart, Australia, 22 October-2 November 2018. CCAMLR, Hobart, Australia.

Commission for the Conservation of Southern Bluefin Tuna (CCSBT). 1999. Report of the Sixth Annual Meeting, First Part, 29-30 November 1999. CCSBT, Canberra, Australia.

Commission for the Conservation of Southern Bluefin Tuna (CCSBT). 2015. Strategic plan for the Commission for the Conservation of Southern Bluefin Tuna 2015-2020, Attachment 14 to the Report of the Twenty-Second Annual Meeting of the Commission held in Yeosu, South Korea, 12-15 October. CCSBT, Canberra, Australia.

Commission for the Conservation of Southern Bluefin Tuna (CCSBT). 2017. Report of the Extended Commission of the Twenty-Fourth Annual Meeting of the Commission, 12 October, Yogyakarta, Indonesia. CCSBT, Canberra, Australia.
Commission for the Conservation of Southern Bluefin Tuna (CCSBT). 2018. Report of the Extended Commission of the Twenty-Fifth Annual Meeting of the Commission, 15-18 October 2018, Noumea, New Caledonia. CCSBT, Canberra, Australia.

Convention on Biological Diversity (CBD). 2000. Decision V/6 on Ecosystem approach. Secretariat of the Convention on Biological Diversity, Montréal, Québec, Canada. [online] URL: https://www.cbd.int/decision/cop/?id=7148

Cosens, B. A., R. K. Craig, S. L. Hirsch, C. A. (T.) Arnold, M. H. Benso, D. A. DeCaro, A. S. Garmestani, H. Gosnell, J. B. Ruhl and E. Schlager. 2017. The role of law in adaptive governance. Ecology and Society 22(1):30. https://doi.org/10.5751/ES-08731-220130

Craig, R. K. 2010. Stationarity is dead - long live transformation: five principles for climate change adaptation law. Harvard Environmental Law Review 34:9-73.

Craig, R. K. 2013. Learning to think about complex environmental systems in environmental and natural resource law and legal scholarship: a twenty-year retrospective. Fordham Environmental Law Review 24:87-102.

Craig, R. K. 2017. Putting resilience theory into practice: the example of fisheries management. Natural Resources \& Environment 31(3):3-7.

de Caro, D. A., B. C. Chaffin, E. Schlager, A. S. Garmestani and J. B. Ruhl. 2017. Legal and institutional foundations of adaptive environmental governance. Ecology and Society 22(1):32. https:// doi.org/10.5751/ES-09036-220132

de Young, C., D. Soto, T. Bahri, and D. Brown. 2012. Building resilience for adaptation to climate change in the fisheries and aquaculture sector. Pages 103-116 in A. Meybeck, J. Lankoski, S. Redfern, N. Azzu and V. Gitz, editors. Building resilience for adaptation to climate change in the agriculture sector. Proceedings of A Joint FAO/OECD Workshop, 23-24 April 2012. Food and Agriculture Organization, Organisation for Economic Cooperation and Development, Rome, Italy.

Diekert, F. K., and E. Nieminen. 2017. International fisheries agreements with a shifting stock. Dynamic Games and Applications 7:185-211. https://doi.org/10.1007/s13235-016-0184-4

Diz Pereira Pinto, D. D. 2012. Fisheries management in areas beyond national jurisdiction: the impact of ecosystem-based lawmaking. Martinus Nijhoff, Leiden, The Netherlands. https://doi. org/10.1163/9789004242005

Doremus, H. 2010. Adapting to climate change through law that bends without breaking. San Diego Journal of Climate \& Energy Law 2:45-85.

Engler, C. 2010. Allocation of fishing opportunities in regional fisheries management organizations: a legal analysis in the light of equity. LLM Thesis, Dalhousie University, Halifax, Nova Scotia, Canada.

Engler, C. 2015. Beyond rhetoric: navigating the conceptual tangle towards effective implementation of the ecosystem approach to oceans management. Environmental Reviews 23:288. https://doi. org/10.1139/er-2014-0049 
European Union (EU). 2013. Regulation (EU) No 1380/2013 of the European Parliament and of the Council of 11 December 2013 on the common fisheries policy, OJ L 354, 28.12.2013. EU, Brussels, Belgium.

Food and Agriculture Organization of the United Nations (FAO). 2002. The Reykjavik Declaration on Responsible Fisheries in the Marine Ecosystem. In FAO. Report of the Reykjavik Conference on Responsible Fisheries in the Marine Ecosystem, Reykjavik, Iceland, 1-4 October 2001. FAO Fisheries Report No. 658, Appendix I. FAO, Rome, Italy.

Food and Agriculture Organization of the United Nations (FAO). 2003. The ecosystem approach to fisheries. FAO Technical Guidelines for Responsible Fisheries. No. 4, Suppl. 2. FAO, Rome, Italy.

Food and Agriculture Organization of the United Nations (FAO). 2009. International guidelines for the management of deep-sea fisheries in the high seas. FAO, Rome, Italy.

Food and Agriculture Organization of the United Nations (FAO). 2016. Report of the Sixth Meeting of the Regional Fishery Body Secretariats' Network, Rome, Italy, 9 and 15 July 2016. FAO Fisheries and Aquaculture Report No. 1175. FAO, Rome, Italy.

Food and Agriculture Organization of the United Nations/ Global Environment Facility (FAO/GEF). 2016. Report of the Joint Meeting of Tuna RFMOs on the implementation of the ecosystem approach to fisheries management, 12-14 December. FAO, Rome, Italy. [online] URL: http://www.fao.org/fileadmin/ user_upload/common_oceans/docs/JointTunaRFMO_EBFM_Meeting. pdf

Freestone, D. 2009. Climate change and the oceans. Carbon \& Climate Law Review 4:383-386.

Freestone, D., D. Johnson, J. Ardron, K. Killerlain Morrison, and S. Unger. 2014. Can existing institutions protect biodiversity in areas beyond national jurisdiction? Experiences from two ongoing processes. Marine Policy 49:167-175. https://doi. org/10.1016/j.marpol.2013.12.007

Friedman, K., S. M. Garcia and J. Rice. 2018. Mainstreaming biodiversity in fisheries. Marine Policy 95:209-220. https://doi. org/10.1016/j.marpol.2018.03.001

Frohlich, M. F., C. Jacobson, P. Fidelman, and T. F. Smith. 2018. The relationship between adaptive management of socialecological systems and law: a systematic review. Ecology and Society 23(2):23. http://dx.doi.org/10.5751/ES-10060-230223

Grafton, R. Q. 2010. Adaptation to climate change in marine capture fisheries. Marine Policy 34:606-615. https://doi. org/10.1016/j.marpol.2009.11.011

Green, O. O., A. S. Garmestani, C. R. Allen, L. H. Gunderson, J. B. Ruhl, C. A. Arnold, N. A. J. Graham, B. Cosens, D. G. Angeler, B. C. Chaffin, and C. S. Holling. 2015. Barriers and bridges to the integration of social-ecological resilience and law. Frontiers in Ecology and the Environment 13(6):332-337. https:// doi.org/10.1890/140294

Haas, B., J. McGee, A. Fleming, and M. Haward. 2020. Factors influencing the performance of regional fisheries management organizations. Marine Policy 113:103787. https://doi.org/10.1016/ j.marpol.2019.103787
Harrison, J. 2019. Key challenges relating to the governance of regional fisheries. Pages 79-102 in R. Caddell and E. J. Molenaar, editors. Strengthening international fisheries law in an era of changing oceans. Hart, Oxford, UK. https://doi.org/10.5040/9781509923373.ch-005

Heenan, A., R. Pomeroy, J. Bell, P. L. Munday, W. Cheung, C. Logan, R. Brainard, A. Y. Amri, P. Aliño, N. Armada, L. David, R. Rivera-Guieb, S. Green, J. Jompa, T. Leonardo, S. Mamauag, B. Parker, J. Shackeroff, and Z. Yasin. 2015. Climate-informed ecosystem approach to fisheries management. Marine Policy 57:182-192. https://doi.org/10.1016/j.marpol.2015.03.018

Hoegh-Guldberg, O., R. Cai, E. S. Poloczanska, P. G. Brewer, S. Sundby, K. Hilmi, V. J. Fabry, and S. Jung. 2014. The ocean. Pages 1655-1731 in V. R. Barros, C. B. Field, D. J. Dokken, M. D. Mastrandrea, K. J. Mach, T. E. Bilir, M. Chatterjee, K. L. Ebi, Y. O. Estrada, R. C. Genova, B. Girma, E. S. Kissel, A. N. Levy, S. MacCracken, P. R. Mastrandrea, and L. L.White, editors. Climate change 2014: impacts, adaptation, and vulnerability. Part B: regional aspects. Contribution of Working Group II to the Fifth Assessment Report of the Intergovernmental Panel on Climate Change. Cambridge University Press, Cambridge, UK.

Humby, T.-L. 2014. Law and resilience: mapping the literature. Seattle Journal of Environmental Law 4(1):85-130.

Indian Ocean Tuna Commission (IOTC). 2019. Report of the 5 th Technical Committee on Allocation Criteria Victoria, Mahé, Seychelles, 11-13 March 2019. IOTC, Victoria, Seychelles.

Intergovernmental Panel on Climate Change (IPCC). 2019. Special report on the ocean and cryosphere in a changing climate. H.-O. Pörtner, D. C. Roberts, V. Masson-Delmotte, P. Zhai, M. Tignor, E. Poloczanska, K. Mintenbeck, M. Nicolai, A. Okem, J. Petzold, B. Rama and N. Weyer, editors. In press.

International Commission for the Conservation of Atlantic Tunas (ICCAT). 2016. Resolution by ICCAT on criteria for the allocation of fishing possibilities, adopted by the 24th Regular Meeting of the Commission held in St. Julians, Malta, 10-17 November 2015. In Report for biennial period, 2014-15 PART II (2015), Vol. 1. ICCAT, Madrid, Spain.

Juan-Jordá, M. J., H. Murua, H. Arrizabalaga, N. Dulvy, and V. Restrepo. 2018. Report card on ecosystem-based fisheries management in tuna regional fisheries management organizations. Fish and Fisheries 19(2):321-339. https://doi.org/10.1111/ faf.12256

Karkkainen, B. C. 2002. Collaborative ecosystem governance: scale, complexity, and dynamism. Virginia Environmental Law Journal 21:189-243.

Koen-Alonso, M., P. Pepin, M. J. Fogarty, A. Kenny, and E. Kenchington. 2019. The Northwest Atlantic Fisheries Organization Roadmap for the development and implementation of an ecosystem approach to fisheries: structure, state of development, and challenges. Marine Policy 100:342-352. https:// doi.org/10.1016/j.marpol.2018.11.025

Koubrak, O., and D. L. VanderZwaag. 2020. Are transboundary fisheries management arrangements in the Northwest Atlantic and North Pacific seaworthy in a changing ocean? Ecology and Society 25(4):42. https://doi.org/10.5751/ES-11835-250442 
Kvalvik, I. 2012. Managing institutional overlap in the protection of marine ecosystems on the high seas: the case of the North East Atlantic. Ocean \& Coastal Management 56:35-43. https://doi. org/10.1016/j.ocecoaman.2011.09.009

Kvamsdal, S. F., A. Eide, N.-A. Ekerhovd, K. Enberg, A. Gudmundsdottir, A. H. Hoel, K. E. Mills, F. J. Mueter, L. RavnJonsen, L. K. Sandal, J. E. Stiansen, and N. Vestergaard. 2016. Harvest control rules in modern fisheries management. Elementa: Science of the Anthropocene 4:000114. https://doi.org/10.12952/ journal.elementa.000114

Link, J. S., and H. I. Browman. 2014. Integrating what? Levels of marine ecosystem-based assessment and management. ICES Journal of Marine Science 71(5):1170-1173. https://doi. org/10.1093/icesjms/fsu026

Long, R. D., A. Charles and R. L. Stephenson. 2015. Key principles of marine ecosystem-based management. Marine Policy 57:53-60. https://doi.org/10.1016/j.marpol.2015.01.013

McIlgorm, A., S. Hanna, G. Knapp, P. Le Floc'H, F. Millerd, and M. Pan. 2010. How will climate change alter fishery governance? Insights from seven international case studies. Marine Policy 34:170-177. https://doi.org/10.1016/i.marpol.2009.06.004

Molenaar, E. J. 2000. The concept of "real interest" and other aspects of co-operation through regional fisheries management mechanisms. International Journal of Marine and Coastal Law 15 (4):475-531. https://doi.org/10.1163/157180800X00226

Molenaar, E. J. 2002. Ecosystem-based fisheries management, commercial fisheries, marine mammals and the 2001 Reykjavik Declaration in the context of international law. International Journal of Marine and Coastal Law 17(4):561-595.

Molenaar, E. J. 2003. Participation, allocation and unregulated fishing: the practice of regional fisheries management organisations. International Journal of Marine and Coastal Law 18(4):457-480. https://doi.org/10.1163/157180803322710985

Molenaar, E. J. 2019. Participation in regional fisheries management organizations. Pages 103-130 in R. Caddell and E. J. Molenaar, editors. Strengthening international fisheries law in an era of changing oceans. Hart, Oxford, UK. https://doi. org/10.5040/9781509923373.ch-006

Molenaar, E. J., and R. Caddell. 2019. International fisheries law: achievements, limitations and challenges. Pages 3-10 in R. Caddell and E. J. Molenaar, editors. Strengthening international fisheries law in an era of changing oceans. Hart, Oxford, UK. https://doi. org/10.5040/9781509923373.ch-001

North East Atlantic Fisheries Commission (NEAFC). 2017. Guidelines for coastal State consultations in the North East Atlantic, adopted during the 36th Annual Meeting of the NorthEast Atlantic Fisheries Commission, 13-17 November 2017, Annex $N$ to the 2017 Annual Meeting Report. NEAFC, London, UK. [online] URL: https://www.neafc.org/node/16449

Northwest Atlantic Fisheries Organization (NAFO). 2018. NAFO Performance Review: Panel Report. NAFO, Halifax, Nova Scotia, Canada.

Northwest Atlantic Fisheries Organization (NAFO). 2019. Conservation and enforcement measures 2019. NAFO COM Doc.
19-01 Serial No. N6901. NAFO, Halifax, Nova Scotia, Canada. [online] URL: https://www.nafo.int/Portals/0/PDFs/COM/2019/ comdoc19-01.pdf

Ojea, E., I. Pearlman, S. D. Gaines and S. E. Lester. 2017. Fisheries regulatory regimes and resilience to climate change. Ambio 46:399-412. https://doi.org/10.1007/s13280-016-0850-1

Organisation for Economic Co-operation and Development (OECD). 2010. The economics of adapting fisheries to climate change. OECD Publishing, Paris, France. http://dx.doi. org/10.1787/9789264090415-en

Orrego Vicuña, F. 1999. The changing international law of high seas fisheries. Cambridge University Press, Cambridge, New York.

Ortuño Crespo, G., J. Mossop, D. Dunn, K. Gjerde, E. Hazen, G. Reygondeau, R. Warner, D. Tittensor, and P. Halpin. 2020. Beyond static spatial management: scientific and legal considerations for dynamic management in the high seas. Marine Policy 104102 (in press). https://doi.org/10.1016/j.marpol.2020.104102

Owen, D. 2013. Mapping, modeling, and the fragmentation of environmental law. Utah Law Review 2013:219-281.

Palacios-Abrantes, J., U. R. Sumaila, and W. W. L. Cheung. 2020. Challenges to transboundary fisheries management in North America under climate change. Ecology and Society 25(4):41. https://doi.org/10.5751/ES-11743-250441

Pentz, B., and N. Klenk. 2017. The 'responsiveness gap' in RFMOs: The critical role of decision-making policies in the fisheries management response to climate change. Ocean \& Coastal Management 145:44-51. https://doi.org/10.1016/j. ocecoaman.2017.05.007

Pentz, B., and N. Klenk. 2020. Understanding the limitations of current RFMO climate change adaptation strategies: the case of the IATTC and the Eastern Pacific Ocean. International Environmental Agreements: Politics, Law and Economics 20:21-39. https://doi.org/10.1007/s10784-019-09452-9

Pinsky, M. L., and N. J. Mantua. 2014. Emerging adaptation approaches for climate-ready fisheries management. Oceanography 27(4):146-159. http://dx.doi.org/10.5670/oceanog.2014.93

Pinsky, M. L., G. Reygondeau, R. Caddell, J. Palacios-Abrantes, J. Spijkers, and W. W. L. Cheung. 2018. Preparing ocean governance for species on the move. Science 360(6394):1189-1191. https://doi.org/10.1126/science.aat2360

Porter, J. R., L. Xie, A. J. Challinor, K. Cochrane, S. M. Howden, M. M. Iqbal, D. B. Lobell, and M. I. Travasso. 2014. Food security and food production systems. Pages 485-533 in C. B. Field, V. R. Barros, D. J. Dokken, K. J. Mach, M. D. Mastrandrea, T. E. Bilir, M. Chatterjee, K. L. Ebi, Y. O. Estrada, R. C. Genova, B. Girma, E. S. Kissel, A. N. Levy, S. MacCracken, P. R. Mastrandrea, and L. L.White, editors. Climate change 2014: impacts, adaptation, and vulnerability. Part A: global and sectoral aspects. Contribution of Working Group II to the Fifth Assessment Report of the Intergovernmental Panel on Climate Change. Cambridge University Press, Cambridge, UK.

Rayfuse, R. 2015. Regional fisheries management organisations and their efforts and measures to regulate fishing activities. Pages 
152-176 in H. J. Koch, D. König, J. Sanden, and R. Verheyen, editors. Legal regimes for environmental protection: governance for climate change and ocean resources. Brill Nijhoff, Boston, USA. https://doi.org/10.1163/9789004302839_011

Rayfuse, R. 2018. Climate change and Antarctic fisheries: ecosystem management in CCAMLR. Ecology Law Quarterly 45 (1):53-81.

Rayfuse, R. 2019. Addressing climate change impacts in regional fisheries management organizations. Pages 247-268 in R. Caddell and E. J. Molenaar, editors. Strengthening international fisheries law in an era of changing oceans. Hart, Oxford, UK. https://doi. org/10.5040/9781509923373.ch-011

Reid, K. 2018. Climate change impacts, vulnerabilities and adaptations: Southern Ocean marine fisheries. Pages 363-374 in M. Barange, T. Bahri, M. C. M. Beveridge, K. L. Cochrane, S. Funge-Smith, and F. Poulain, editors. Impacts of climate change on fisheries and aquaculture: synthesis of current knowledge, adaptation and mitigation options. FAO Fisheries and Aquaculture Technical Paper No. 627. Food and Agriculture Organization, Rome, Italy.

Ruhl, J. B. 2010. Climate change adaptation and the structural transformation of environmental law. Environmental Law 40:363-435.

Scott, K. 2011. International environmental governance: managing fragmentation through institutional connection. Melbourne Journal of International Law 12:1-40.

Scott, K. 2017. Climate change and the oceans: navigating legal orders. Pages 124-150 in M. H. Nordquist, J. N. Moore, and R. Long, editors. Legal order in the world's oceans: UN Convention on the Law of the Sea. Brill Nijhoff, Leiden, The Netherlands. https://doi.org/10.1163/9789004352544007

Shaw, M. R., J. T. Overpeck, and G. F. Midgley. 2014. Crosschapter box on ecosystem based approaches to adaptationemerging opportunities. Pages 101-103 in V. R. Barros, C. B. Field, D. J. Dokken, M. D. Mastrandrea, K. J. Mach, T. E. Bilir, M. Chatterjee, K. L. Ebi, Y. O. Estrada, R. C. Genova, et al., editors. Climate change 2014: impacts, adaptation, and vulnerability. Part B: regional aspects. Contribution of Working Group II to the Fifth Assessment Report of the Intergovernmental Panel on Climate Change. Cambridge University Press, Cambridge, UK.

Sigler, M., A. Hollowed, K. Holsman, S. Zador, A. Haynie, A. Himes-Cornell, P. Mundy, S. Davis, J. Duffy-Anderson, T. Gelatt, et al. 2016. Alaska regional action plan for the southeastern Bering Sea. NOAA Fisheries Climate Science Strategy. NOAA Technical Memorandum NMFS-AFSC-336. U.S. Department of Commerce, National Marine Fisheries Service, Silver Spring, Maryland, USA.

Smith, D., and J. Jabour. 2018. MPAs in ABNJ: lessons from two high seas regimes. ICES Journal of Marine Science 75(1):417-425. https://doi.org/10.1093/icesjms/fsx189

Smith, D., J. McGee, and J. Jabour. 2016. Marine protected areas: a spark for contestation over 'rational use' of Antarctic marine living resources in the Southern Ocean? Australian Journal of Maritime and Ocean Affairs 8(3):180-198. https://doi. org/10.1080/18366503.2016.1229398
Stokke, O. S. 2019. Management options for high seas fisheries: making regime complexes more effective. Pages 51-78 in $\mathrm{R}$. Caddell and E. J. Molenaar, editors. Strengthening international fisheries law in an era of changing oceans. Hart, Oxford, UK. https://doi.org/10.5040/9781509923373.ch-004

Sumaila, U. R., J. Palacios-Abrantes, and W. W. L. Cheung. 2020. Climate change, shifting threat points, and the management of transboundary fish stocks. Ecology and Society 25(4):40. https:// doi.org/10.5751/ES-11660-250440

Telesetski, A. 2014. "Good faith" obligations to protect and preserve the marine environment: a proposal on uniform high seas fisheries management. Pages 449-471 in C. Schofield, S. Lee, and M.-S. Kwon, editors. The limits of maritime jurisdiction. Martinus Nijhoff, Leiden, The Netherlands. https://doi. org/10.1163/9789004262591_023

Tladi, D. 2015. The proposed implementing agreement: options for coherence and consistency in the establishment of protected areas beyond national jurisdiction. International Journal of Marine and Coastal Law 30:654-673. https://doi. org/10.1163/15718085-12341375

Tudela, S., and K. Short. 2005. Paradigm shifts, gaps, inertia, and political agendas in ecosystem-based fisheries management. Marine Ecology Progress Series 300:282-286. https://doi. org/10.3354/meps300282

United Nations (UN). 2002. Plan of implementation of the World Summit on Sustainable Development, Report of the World Summit on Sustainable Development, Johannesburg, South Africa, 26 August-4 September. UN Doc A/CONF/199/20, Chapter 1, Resolution 2, Annex. UN, New York, New York, USA. [online] URL: https://sustainabledevelopment.un.org/index.php?page= view \& type $=2002 \& n r=101 \&$ menu $=35$

United Nations (UN). 2015. Sustainable Development Goal 14.2 and target 14.2.1. UN, New York, New York, USA. [online] URL: https://sustainabledevelopment.un.org/sdg14

United Nations Conference on Environment and Development (UNCED). 1992. Agenda 21: Programme of Action for Sustainable Development, UN Doc A/CONF.151/26/Rev.1 (Vo1. I) (12 August 1992), Annex II. UN, New York, New York, USA.

United Nations Environment Programme (UNEP). 2016. Regional oceans governance: making regional seas programmes, regional fishery bodies and large marine ecosystem mechanisms work better together. UNEP Regional Seas Reports and Studies No. 197. UNEP, Nairobi, Kenya.

United Nations Fish Stocks Agreement (UNFSA) Review Conference. 2006. Report of the Review Conference on the Agreement for the Implementation of the Provisions of the United Nations Convention on the Law of the Sea of 10 December 1982 relating to the Conservation and Management of Straddling Fish Stocks and Highly Migratory Fish Stocks prepared by the President of the Conference, A/CONF.210/2006/15 (5 July 2006). UN, New York, New York, USA.

United Nations Fish Stocks Agreement (UNFSA) Review Conference. 2010. Report of the resumed Review Conference on the Agreement for the Implementation of the Provisions of the 
United Nations Convention on the Law of the Sea of 10 December 1982 relating to the Conservation and Management of Straddling Fish Stocks and Highly Migratory Fish Stocks prepared by the President of the Conference, A/CONF.210/2010/7 (27 July 2010). UN, New York, New York, USA.

United Nations Fish Stocks Agreement (UNFSA) Review Conference. 2016. Report of the resumed Review Conference on the Agreement for the Implementation of the Provisions of the United Nations Convention on the Law of the Sea of 10 December 1982 relating to the Conservation and Management of Straddling Fish Stocks and Highly Migratory Fish Stocks prepared by the President of the Conference, A/CONF.210/2016/5 (1 August 2016). UN, New York, New York, USA.

United Nations General Assembly (UNGA). 2006. Resolution 61/105 on sustainable fisheries, including through the 1995 Agreement for the Implementation of the Provisions of the United Nations Convention on the Law of the Sea of 10 December 1982 relating to the Conservation and Management of Straddling Fish Stocks and Highly Migratory Fish Stocks, and related instruments, UN Doc A/RES/61/105 (6 March 2007).

United Nations General Assembly (UNGA). 2009. Resolution 64/72 adopted by the General Assembly on 4 December 2009 on sustainable fisheries, including through the 1995 Agreement for the Implementation of the Provisions of the United Nations Convention on the Law of the Sea of 10 December 1982 relating to the Conservation and Management of Straddling Fish Stocks and Highly Migratory Fish Stocks, and related instruments, UN Doc A/RES/64/72 (19 March 2010).

United Nations General Assembly (UNGA). 2018. Resolution 72/249 adopted by the General Assembly on 24 December 2017 on international legally binding instrument under the United Nations Convention on the Law of the Sea on the conservation and sustainable use of marine biological diversity of areas beyond national jurisdiction, UN Doc A/RES/72/249 (19 January 2018).

United Nations General Assembly (UNGA). 2019. Resolution $73 / 125$ on sustainable fisheries, adopted by the General Assembly on 11 December 2018, A/RES/73/125 (15 January 2019).

United Nations General Assembly (UNGA). 2020. Revised draft text of an agreement under the United Nations Convention on the Law of the Sea on the conservation and sustainable use of marine biological diversity of areas beyond national jurisdiction. Note by the President. A/CONF.232/2020/3 (18 November 2019). UN, New York, New York, USA.

UN Secretary-General. 2018. Gaps in international environmental law and environment-related instruments: towards a global pact for the environment. Report of the Secretary-General to the UN General Assembly, UN Doc A/73/419 (30 November 2018). UN, New York, New York, USA.

Western and Central Pacific Fisheries Commission (WCPFC). 2019. Summary Report of the Sixteenth Regular Session of the Commission, Port Moresby, Papua New Guinea, 5-11 December 2019. WCPFC, Kolonia, Micronesia. [online] URL: https://www. wcpfc.int/meetings/wcpfc16

Wolfrum, R., and N. Matz. 2000. The interplay of the United Nations Convention on the Law of the Sea and the Convention on Biological Diversity. Pages 445-480 in J. A. Frowein and R. Wolfrum, editors. Max Planck yearbook of United Nations law. Martinus Nijhoff, Leiden, The Netherlands. https://doi. org/10.1163/187574100x00142

Wolfrum, R., and N. Matz. 2003. Conflicts in international environmental law. Springer, Berlin, Germany.

Wright, G., J. Rochette, L. Blom, D. Currie, C. Durussel, K. Gjerde, and S. Unger. 2016. High seas fisheries: what role for a new international instrument? Study $\mathrm{n}^{\circ} 03 / 2016$. Institute for Sustainable Development and International Relations, Paris, France. 